\title{
CINNAMIC ACID AND ITS DERIVATIVES IN THE HERBAL MIXTURES AND THEIR ANTIDIABETIC ACTIVITY
}

\author{
ALONA SAVYCH $^{1} *$, SVITLANA MARCHYSHYN $^{1 *}$, MARIIA KYRYLIV $^{2 \#}$, IRYNA BEKUS $^{2 \#}$ \\ ${ }^{I}$ Department of Pharmacognosy with Medical Botany, I. Horbachevsky Ternopil National Medical University, Ukraine \\ ${ }^{2}$ Department of General Chemistry, I. Horbachevsky Ternopil National Medical University, Ukraine
}

*corresponding author: alonasavych@gmail.com

${ }^{\#}$ Authors with equal contribution.

Manuscript received: February 2021

\begin{abstract}
Due to the wide range of biologically active substances the herbal mixtures can influence in many ways of the pathogenic mechanism of diabetes mellitus development and its complications. Cinnamic acid and its derivatives deserve a particular attention due to their antidiabetic and antioxidant properties. We investigated five samples of herbal mixtures which contained vegetal product with potential high content of these compounds. Using HPLC analysis we evaluated the content of 4 derivatives of cinnamic acid, namely chlorogenic, caffeic, ferulic and sinapic acid in the sample 1 of the herbal mixture; cinnamic acid and 4 of its derivatives, such as chlorogenic, $p$-coumaric, ferulic and sinapic acid in the samples 2 - 5. Our results showed that the predominant phenolic acid was chlorogenic and its content was $149.8 \mu \mathrm{g} / \mathrm{g}$ in the first sample, 180.1 $\mu \mathrm{g} / \mathrm{g}$ in the second sample, $306.7 \mu \mathrm{g} / \mathrm{g}$ in sample $3,182.7 \mu \mathrm{g} / \mathrm{g}$ in sample 4 and $257.57 \mu \mathrm{g} / \mathrm{g}$ in sample 5 . During the assay of in vitro antidiabetic activity we evaluated the inhibitory potential of $\alpha$-amylase and $\alpha$-glucosidase. Our results showed that the herbal mixtures considered may be of potential use as antidiabetics.
\end{abstract}

\section{Rezumat}

Datorită gamei largi de substanțe biologic active, amestecurile de produse vegetale pot influența dezvoltarea diabetului zaharat și complicațiile acestuia. Acidul cinamic și derivații săi au proprietăți antidiabetice și antioxidante. S-au investigat cinci eșantioane de amestecuri de plante cu un conținut potențial ridicat al acestor compuși. Folosind analiza HPLC s-au evaluat cantitativ 4 derivați ai acidului cinamic, și anume acizii clorogenic, cafeic, ferulic și sinapic din proba 1 a amestecului de plante; acid cinamic și 4 derivații ai săi, acizii clorogenic, p-cumaric, ferulic și sinapic, în probele 2 - 5. Rezultatele noastre au arătat că acidul fenolic predominant a fost acidul clorogenic, cu un conţinut de $149,8 \mu \mathrm{g} / \mathrm{g}$ în prima probă, $180,1 \mu \mathrm{g} / \mathrm{g}$ în a doua probă, $306,7 \mu \mathrm{g} / \mathrm{g}$ în proba $3,182,7 \mu \mathrm{g} / \mathrm{g}$ în proba 4 și $257,57 \mu \mathrm{g} / \mathrm{g}$ în proba 5. În timpul testării activitătii antidiabetice in vitro am evaluat potențialul inhibitor al produselor vegetale asupra $\alpha$-amilazei și $\alpha$-glucozidazei. Rezultatele studiului au arătat că amestecurile de produse vegetale studiate au potențial antidiabetic.

Keywords: diabetes mellitus, vegetal products, cinnamic acid, chlorogenic acid, $p$-coumaric acid, ferulic acid, sinapic acid

\section{Introduction}

Diabetes mellitus is one of the most important health issues worldwide, which requires immediate solutions, as the epidemiological situation is alarming the number of patients is growing rapidly each year, leading to increased disability and mortality due to the development of macro- and microangiopathies [3]. According to the official data of the International Diabetes Federation (2019), the incidence of diabetes in the world is projected to increase 1.5 times by 2030 , amounting to more than 500 thousand patients [11]. An important problem of pharmacovigilance is that existing pharmacotherapy can effectively reduce hyperglycaemia, but it is not always able to stabilize fluctuations in glycaemic values during the day and maintain it at an optimal level. This leads to the formation of a cascade of pathological processes excessive glycation and inactivation of the body's antioxidant defence system, triggering the processes of free radical oxidation of lipids and, as a consequence, the development of oxidative stress, which leads to the development and progression of diabetic angiopathies $[3,23]$. Therefore, the optimization of existing antidiabetic pharmacotherapy, research and development of new drugs for the prevention and treatment of this disease and its complications are currently very important issues in modern pharmacy and medicine.

One of these areas is using herbal remedies, either as monotherapy for the prevention or in the mild stages of the disease or in the combination with traditional therapy in more severe forms of the disease [13, 15, 17]. Phytotherapy is a justified method for the prevention and treatment because it has some advantages, such as relatively low toxicity, mild pharmacological effects and possibility to be used for long periods without significant side-effects, and it often well combines with synthetic drugs $[8,17,20]$. 
Particular attention should be paid to the combinations of different medicinal plants, because such herbal mixtures will have more biologically active substances (phytocomplexes) that may influence many aspects of the pathogenic mechanism of diabetes mellitus development and its complications [26, 27]. In this regard, some important biologically active substances are the polyphenols [9]. They comprise a wide range of phytochemical compounds from the following groups: phenolic acids, flavonoids, tannins, stilbenes, coumarins, lignans. Phenolic acids are usually classified into two major groups: benzoic acids, containing seven carbon atoms (C6-C1), and cinnamic acids, comprising nine carbon atoms (C6-C3) [33]. Among various biological activities, cinnamic acid and its derivatives are associated with the ameliorating effects on diabetes and its complications, mainly due to the presence of hypoglycaemic and antioxidant activities [1, 12]. Their antidiabetic effect is implemented by different mechanisms of action, including stimulation of insulin secretion, improvement of pancreatic $\beta$-cell functionality, inhibition of gluconeogenesis, intensification of glucose uptake, delay of carbohydrate digestion and glucose absorption, inhibition of protein glycation and insulin fibrillation. The antioxidant activity of these compounds is due to the fact that cinnamic acid and its derivatives neutralize free radicals by cleavage of the hydrogen atom $[1,2,12,18]$.

Thus, for this purpose, it becomes useful to study the phytochemical compounds, namely the cinnamic acid and its derivatives from the group of phenolic acids within the herbal mixtures with previously in vivo antidiabetic activity investigated [25].

\section{Materials and Methods}

\section{Plant materials}

The herbal raw materials harvested from June to August 2019 in the Ternopil region (Ukraine) were used. After harvesting, the raw materials were dried, crushed and stored according to the general GACP requirements [36]. The plants were identified in the Department of Pharmacognosy with Medical Botany, I. Ya. Horbachevsky Ternopil National Medical University, Ternopil, Ukraine. The voucher specimens of herbal raw materials have been deposited in the departmental herbarium for future records. For the study, five different herbal mixtures with reliable antidiabetic activity established during in vivo pharmacological studies [25] were used. The composition of the mixtures is given in Table I.

Table I

Composition of the herbal mixtures

\begin{tabular}{|c|c|c|c|}
\hline Herbal mixtures & Herbal drug component & Percentage in the mixture (\%) & Relative ratio \\
\hline \multirow{5}{*}{ Sample 1} & Urtica dioica leaf & 26.32 & 5 \\
\hline & Cichorium intybus roots & 26.32 & 5 \\
\hline & Rosa majalis fruits & 21.05 & 4 \\
\hline & Elymus repens rhizome & 15.79 & 3 \\
\hline & Taraxacum officinale roots & 10.52 & 2 \\
\hline \multirow{5}{*}{ Sample 2} & Arctium lappa roots & 26.32 & 5 \\
\hline & Elymus repens rhizome & 26.32 & 5 \\
\hline & Zea mays columns with stigmas & 21.05 & 4 \\
\hline & Helichrysum arenarium flowers & 15.79 & 3 \\
\hline & Rosa majalis fruits & 10.52 & 2 \\
\hline \multirow{6}{*}{ Sample 3} & Inula helenium rhizome with roots & 10.0 & 1 \\
\hline & Helichrysi arenarium flowers & 20.0 & 2 \\
\hline & Zea mays columns with stigmas & 20.0 & 2 \\
\hline & Origanum vulgari herb & 20.0 & 2 \\
\hline & Rosa majalis fruits & 20.0 & 2 \\
\hline & Taraxacum officinale roots & 10.0 & 1 \\
\hline \multirow{5}{*}{ Sample 4} & Cichorium intybus roots & 26.32 & 5 \\
\hline & Elymus repens rhizome & 26.32 & 5 \\
\hline & Helichrysum arenarium flowers & 21.05 & 4 \\
\hline & Rosa majalis fruits & 15.79 & 3 \\
\hline & Zea mays columns with stigmas & 10.52 & 2 \\
\hline \multirow{5}{*}{ Sample 5} & Urtica dioica leaf & 20.0 & 1 \\
\hline & Taraxacum officinale roots & 20.0 & 1 \\
\hline & Vaccinium myrtillus leaf & 20.0 & 1 \\
\hline & Rosa majalis fruits & 20.0 & 1 \\
\hline & Mentha piperita herb & 20.0 & 1 \\
\hline
\end{tabular}

Chemicals and standards

Chemical reference substances (CRS) of chlorogenic acid, caffeic acid, $p$-coumaric acid, ferulic acid, sinapic acid, cinnamic acid, acarbose were of primary reference standard grade ( $\geq 95 \%$ purity HPLC) and were purchased from Sigma-Aldrich Chemical Company (Germany), as well as $\alpha$-amylase, $\alpha$-glucosidase. Water used in 
the studies was produced by MilliQ Gradient water deionization system (USA).

Extraction of cinnamic acid and its derivatives for HPLC assay

The samples of herbal raw materials were ground into a powder by laboratory mill, then about $500 \mathrm{mg}$ (accurately weighed) was selected and placed into vial with $5-10 \mathrm{~mL}$ of $60 \%$ methanol. The extractions were carried out in an ultrasonic water bath at $80^{\circ} \mathrm{C}$ for 4 hours. The resulting extracts were centrifuged at $3000 \mathrm{rpm}$ and filtered through disposable membrane filters with pores of $0.22 \mu \mathrm{m}$ [30].

Instrumentation and conditions of HPLC analysis

The content of cinnamic acid and its derivatives in the samples of the herbal mixtures was studied by high performance liquid chromatography using 3D LC System from Agilent Technologies 1200 (USA) [22]. The separation was performed on a Zorbax SBAq chromatographic column $(4.6 \mathrm{~mm} \pm 150 \mathrm{~mm}, 3.5$ $\mu \mathrm{m})$ (Agilent Technologies, USA) with thermostat temperature $30^{\circ} \mathrm{C}$, injection volume of samples $4 \mu \mathrm{L}$ and flow rate $0.5 \mathrm{~mL} / \mathrm{min}$ at the gradient elution with the mobile phases - methanol (A) and $0.1 \%$ solution of formic acid in water (B). Elution was performed in a gradient mode: $0 \mathrm{~min}-\mathrm{A}(25 \%)$ : B (75\%); $25 \mathrm{~min}$ - A (75\%):B (25\%); $27 \mathrm{~min}-\mathrm{A}$ (100\%):B (0\%); $35 \mathrm{~min}-\mathrm{A}(100 \%): \mathrm{B}(0 \%)$. The registration of signal was done at $250 \mathrm{~nm}$ and 275 $\mathrm{nm}$ and fixation of absorption spectra in the range of $210-700 \mathrm{~nm}$.

To identify the components, the obtained spectra were analysed by comparing the retention times $\left(t_{R}\right)$ of CRS of cinnamic acid and its derivatives. Quantitative analyses were performed using the peaks areas.

Preparation of extracts

The samples of herbal raw materials $(10 \mathrm{~g})$ were placed into a $100 \mathrm{~mL}$ conical flask with $120 \mathrm{~mL}$ distilled water. The extractions were carried out in a water bath for $30 \mathrm{~min}$. The resulting extracts were filtered using Whatmann filter paper no1. Then the filtrates were evaporated by rotary evaporator and were lyophilized to dryness. The lyophilized powders of each herbal mixture were stored at $4{ }^{\circ} \mathrm{C}$ for further use.

$\alpha$-amylase inhibition
The method is based on enzyme inhibition, so the transformation of starch to reducing oligosaccharides that react with 3,5-dinitrosalicylic acid is blocked. A total of $500 \mu \mathrm{L}$ of samples of the studied extracts with a range of concentrations between 100 and 1000 $\mu \mathrm{g} / \mathrm{mL}$ were added to $500 \mu \mathrm{L}$ of $0.20 \mathrm{mM}$ phosphate buffer ( $\mathrm{pH} 6.9$ with $0.006 \mathrm{M}$ sodium chloride) containing $\alpha$-amylase solution $(0.5 \mathrm{mg} / \mathrm{mL})$ and were incubated at $25^{\circ} \mathrm{C}$ for $10 \mathrm{~min}$. Thereafter, it was added $500 \mu \mathrm{L}$ of $(1 \% \mathrm{w} / \mathrm{v})$ starch solution in $0.02 \mathrm{M}$ sodium phosphate buffer ( $\mathrm{pH} 6.9$ with $0.006 \mathrm{M}$ sodium chloride) to each tube and was incubated at $25^{\circ} \mathrm{C}$ for $10 \mathrm{~min}$. The reaction was stopped with $1.0 \mathrm{~mL}$ of 3,5-dinitrosalicylic acid colour reagent (12.0 $\mathrm{g}$ of sodium potassium tartrate tetrahydrate in $8 \mathrm{~mL}$ of $2 \mathrm{M} \mathrm{NaOH}$ and 96 $\mathrm{mM}$ 3,5-dinitrosalicylic acid solution). Then the tubes were incubated in the boiling water bath for $5 \mathrm{~min}$ and cooled to room temperature. The reaction mixture was diluted by adding $10 \mathrm{~mL}$ of distilled water and absorbance was measured at $540 \mathrm{~nm}$ using the spectrophotometer Shimadzu 1800-UV (Japan). Experiments were performed in triplicate. Acarbose was used as a positive control [21].

$\alpha$-glucosidase inhibition

The method is based on the inhibition of $\alpha$-glucosidase that catalyses the hydrolysis of $p$-nitrophenyl- $D$ glucopyranoside to $p$-nitrophenol. A total of $20 \mu \mathrm{L}$ of samples of the studied extracts with a range of concentrations between 100 and $1000 \mu \mathrm{g} / \mathrm{mL}$ were added to $50 \mu \mathrm{L}$ potassium phosphate buffer $0.1 \mathrm{M}$ (pH 6.8) and $10 \mu \mathrm{L} \alpha$-glucosidase $0.25 \mathrm{U} / \mathrm{mL}$ and were incubated at $37^{\circ} \mathrm{C}$ for $10 \mathrm{~min}$. Then $10 \mu \mathrm{L} 5 \mathrm{mM}$ of $p$-nitrophenyl- $\alpha-D$-glucopyranoside was added and further incubated for $30 \mathrm{~min}$. the reaction was stopped with $50 \mu \mathrm{L}$ of $\mathrm{Na}_{2} \mathrm{CO}_{3} 0.1 \mathrm{M}$. The absorbance was measured at $405 \mathrm{~nm}$ using the spectrophotometer Shimadzu 1800-UV (Japan). Experiments were performed in triplicate. Acarbose was used as a positive control [14].

Calculation of 50\% Inhibitory Concentration (IC50) The inhibitory concentration of the water extracts of the herbal mixtures required to inhibit the activity of the enzyme by $50 \%$, IC50 was calculated by regression analysis using the percentage scavenging activities at five different concentrations of the extracts. Inhibition (I \%) was calculated using the following equation:

$$
\% \text { Inhibition }=\frac{\text { Absorbance of control }- \text { Absorbance of sample }}{\text { Absorbance of control }} \times 100
$$

\section{Results and Discussion}

The evaluation of cinnamic acid and its derivatives in the herbal mixtures

The results of qualitative and quantitative analyses of cinnamic acid and its derivatives in the herbal mixtures are represented in Table II.

During HPLC analysis were identified 4 derivatives of cinnamic acid, such as chlorogenic, caffeic, ferulic and sinapic acids in the sample 1 of herbal mixture; cinnamic acid and 4 its derivatives, such as chlorogenic, $p$-coumaric, ferulic and sinapic acid in the samples 2 - 5 (Table II).

The in-vitro antidiabetic activity

The experimental studies regarding the in vitro antidiabetic activity of the investigated herbal mixtures in a concentrations range of $100-1000 \mu \mathrm{g} / \mathrm{mL}$ were 
FARMACIA, 2021, Vol. 69, 3

performed by inhibition of $\alpha$-amylase and $\alpha$-glucosidase $\quad$ and Table IV).

activity, using with acarbose as reference (Table III

Table II

Content of cinnamic acid and its derivatives in the samples of the herbal mixtures

\begin{tabular}{cclccccc}
\hline \multirow{2}{*}{ No. } & \multirow{2}{*}{$\mathrm{t}_{\mathrm{R}}, \mathrm{min}$} & \multirow{2}{*}{ Identified substance } & \multicolumn{5}{c}{ Active principles $(\mu \mathrm{g} / \mathrm{g})$} \\
\cline { 4 - 7 } & & & Sample 1 & Sample 2 & Sample 3 & Sample 4 & Sample 5 \\
\hline 1. & 10.18 & chlorogenic acid & $149.8 \pm 0.28$ & $180.1 \pm 0.37$ & $306.7 \pm 0.56$ & $182.7 \pm 0.24$ & $257.5 \pm 0.29$ \\
\hline 2. & 10.89 & caffeic acid & $18.9 \pm 0.11$ & - & - & - & - \\
\hline 3. & 13.91 & $p$-coumaric acid & - & $116.2 \pm 0.5$ & $92.5 \pm 0.24$ & $135.7 \pm 0.27$ & $26.1 \pm 0.22$ \\
\hline 4. & 15.16 & ferulic acid & $51.6 \pm 0.21$ & $12.5 \pm 0.15$ & $15.9 \pm 0.18$ & $31.5 \pm 0.16$ & $50.8 \pm 0.19$ \\
\hline 5. & 15.69 & sinapic acid & $28.5 \pm 0.15$ & $36.2 \pm 0.14$ & $33.2 \pm 0.18$ & $55.5 \pm 0.19$ & $25.1 \pm 0.13$ \\
\hline 6. & 18.14 & cinnamic acid & - & $58.8 \pm 0.17$ & $64.2 \pm 0.18$ & $75.7 \pm 0.17$ & $4.5 \pm 0.11$ \\
\hline
\end{tabular}

Values are expressed as mean \pm SD $(n=5)$

Table III

$\alpha$-amylase inhibition of water extracts of the samples of the herbal mixtures

\begin{tabular}{|c|c|c|c|}
\hline Herbal mixtures & Concentration, $\mu \mathrm{g} / \mathrm{mL}$ & Inhibition, $\%$ & $\mathrm{IC} 50, \mu \mathrm{g} / \mathrm{mL}$ \\
\hline \multirow{5}{*}{ Sample 1} & 100 & $22.17 \pm 3.65$ & \multirow{5}{*}{699.49} \\
\hline & 200 & $30.97 \pm 2.98$ & \\
\hline & 400 & $41.15 \pm 3.51$ & \\
\hline & 800 & $52.97 \pm 4.28$ & \\
\hline & 1000 & $61.64 \pm 3.49$ & \\
\hline \multirow{5}{*}{ Sample 2} & 100 & $20.47 \pm 3.31$ & \multirow{5}{*}{758.15} \\
\hline & 200 & $28.58 \pm 4.42$ & \\
\hline & 400 & $39.13 \pm 5.28$ & \\
\hline & 800 & $51.27 \pm 3.63$ & \\
\hline & 1000 & $59.34 \pm 3.75$ & \\
\hline \multirow{5}{*}{ Sample 3} & 100 & $21.58 \pm 3.53$ & \multirow{5}{*}{781.76} \\
\hline & 200 & $32.11 \pm 3.94$ & \\
\hline & 400 & $38.28 \pm 2.37$ & \\
\hline & 800 & $50.56 \pm 3.63$ & \\
\hline & 1000 & $60.18 \pm 3.74$ & \\
\hline \multirow{5}{*}{ Sample 4} & 100 & $20.65 \pm 3.62$ & \multirow{5}{*}{700.17} \\
\hline & 200 & $31.07 \pm 2.86$ & \\
\hline & 400 & $40.95 \pm 3.73$ & \\
\hline & 800 & $53.01 \pm 3.85$ & \\
\hline & 1000 & $58.75 \pm 3.92$ & \\
\hline \multirow{5}{*}{ Sample 5} & 100 & $23.04 \pm 3.76$ & \multirow{5}{*}{646.52} \\
\hline & 200 & $31.65 \pm 4.93$ & \\
\hline & 400 & $42.82 \pm 2.71$ & \\
\hline & 800 & $54.47 \pm 3.83$ & \\
\hline & 1000 & $63.18 \pm 3.17$ & \\
\hline \multirow{5}{*}{ Acarbose (reference) } & 100 & $33.98 \pm 1.92$ & \multirow{5}{*}{246.22} \\
\hline & 200 & $47.37 \pm 2.13$ & \\
\hline & 400 & $58.75 \pm 2.46$ & \\
\hline & 800 & $69.58 \pm 2.06$ & \\
\hline & 1000 & $75.94 \pm 1.99$ & \\
\hline
\end{tabular}

Values are expressed as mean $\pm \mathrm{SD}(\mathrm{n}=3)$

Table IV

$\alpha$-glucosidase inhibition of water extracts of the samples of the herbal mixtures

\begin{tabular}{cccc}
\hline Herbal mixtures & Concentration, $\mu \mathrm{g} / \mathrm{mL}$ & Inhibition, \% & $\mathrm{IC} 50, \mu \mathrm{g} / \mathrm{mL}$ \\
\hline & 100 & $30.69 \pm 3.12$ & \\
Sample 1 & 200 & $41.16 \pm 3.17$ & \\
& 400 & $54.95 \pm 2.98$ & 328.16 \\
& 800 & $62.10 \pm 3.08$ & \\
& 1000 & $73.86 \pm 3.05$ & \\
Sample 2 & 100 & $29.49 \pm 2.92$ & \\
& 200 & $39.58 \pm 3.18$ & \\
& 400 & $52.64 \pm 3.14$ & 359.57 \\
& 800 & $60.86 \pm 3.03$ & \\
\hline
\end{tabular}


FARMACIA, 2021, Vol. 69, 3

\begin{tabular}{cccc}
\hline Herbal mixtures & Concentration, $\mu \mathrm{g} / \mathrm{mL}$ & Inhibition, \% & IC50, $\mu \mathrm{g} / \mathrm{mL}$ \\
\cline { 2 - 4 } Sample 3 & 100 & $28.94 \pm 3.09$ & \\
& 200 & $40.48 \pm 2.67$ & \\
& 400 & $53.82 \pm 2.75$ & 342.73 \\
& 800 & $60.69 \pm 3.04$ & \\
Sample 4 & 1000 & $70.93 \pm 3.15$ & \\
& 100 & $29.83 \pm 3.04$ & \\
& 200 & $38.94 \pm 3.15$ & \\
& 400 & $51.99 \pm 3.03$ & 369.50 \\
& 800 & $64.04 \pm 2.61$ & \\
& 1000 & $70.96 \pm 2.19$ & \\
& 100 & $32.85 \pm 3.08$ & \\
Sample 5 & 200 & $43.91 \pm 3.24$ & \\
& 400 & $57.07 \pm 3.31$ & 292.55 \\
& 800 & $65.19 \pm 2.98$ & \\
& 1000 & $75.38 \pm 2.82$ & \\
& 100 & $42.19 \pm 2.12$ & \\
& 200 & $49.84 \pm 1.98$ & \\
& 400 & $62.11 \pm 1.59$ & 202.62 \\
& 800 & $74.09 \pm 2.37$ & \\
\end{tabular}

Values are expressed as mean \pm SD $(n=3)$

The quantitative determination of cinnamic acid and its derivatives showed that the predominant phenylpropanoid was chlorogenic acid, its content was 149.8 $\mu \mathrm{g} / \mathrm{g}$ in the sample $1 ; 180.1 \mu \mathrm{g} / \mathrm{g}$ in the sample 2 ; $306.7 \mu \mathrm{g} / \mathrm{g}$ in the sample 3; $182.7 \mu \mathrm{g} / \mathrm{g}$ in the sample 4; $257.57 \mu \mathrm{g} / \mathrm{g}$ in the sample 5 (Table II). The high content of chlorogenic acid in the studied mixtures is of interest, because it has a pronounced hypoglycaemic activity, due to the fact that it increases the use of glucose by skeletal muscles, improves glucose tolerance, stimulates insulin secretion by pancreatic $\beta$-cells. In addition, chlorogenic acid has the ability to potentiate the action of insulin, similar to the therapeutic action of metformin - synthetic antidiabetic drug of the biguanide class [19]. It is also important that chlorogenic acid has the ability to regulate lipid metabolism by lowering triglycerides, low-density lipoproteins and cholesterol, which is signify to prevent the development of cardiovascular diseases and microcirculatory complications - diabetic nephropathy, neuropathy and retinopathy, the formation of diabetic foot [24]. Diabetes mellitus is often accompanied by the development of metabolic syndrome, which is characterized by obesity, and chlorogenic acid helps to lose weight and reduce the accumulation of visceral fat, activates fat metabolism in the liver and helps to reduce plasma leptin level [24, 32]. In addition, chlorogenic acid has strong antioxidant properties, which is important for the prevention of diabetic angiopathies, the pathogenesis of which are activation of lipid peroxidation, inactivation of antioxidant protection system and development of oxidative stress. Antioxidant properties of chlorogenic acid are realized by cleavage of hydrogen atoms, which reduces the amount of free radicals, lipid peroxidation products and inhibits the development of oxidative stress [4]. The development of inflammatory processes in patients with diabetes mellitus is an important problem that requires some adjustments to the pharmacotherapy. This problem may be solved by using chlorogenic acid that exhibits anti-inflammatory properties, which decreases the oedema, suppresses the pro-inflammatory cytokines, reduces the neutrophil infiltration [34].

During HPLC analysis it was established the content of $p$-coumaric acid in four samples of herbal mixtures and it was $116.2 \mu \mathrm{g} / \mathrm{g}$ in the second sample, $92.5 \mu \mathrm{g} / \mathrm{g}$ in sample 3, $135.7 \mu \mathrm{g} / \mathrm{g}$ in sample 4 and $26.1 \mu \mathrm{g} / \mathrm{g}$ in sample 5 (Table II). $p$-Coumaric acid has many biological activities, such as hypoglycaemic, important antioxidant, anti-inflammatory, hepato-renal protective effects and protects the pancreas from free radical damage. Thus, $p$-coumaric acid is a good agent for lowering blood glucose, reducing oxidative stress, improving antioxidant status, reducing inflammation [10, 31]. Our study showed that the content of ferulic acid was $51.6 \mu \mathrm{g} / \mathrm{g}$ in sample $1,12.5 \mu \mathrm{g} / \mathrm{g}$ in sample $2,15.9 \mu \mathrm{g} / \mathrm{g}$ in sample $3,31.5 \mu \mathrm{g} / \mathrm{g}$ in sample 4 and $50.8 \mu \mathrm{g} / \mathrm{g}$ in sample 5 (Table II). Ferulic acid is a very important agent for the prevention and treatment of diabetes because it has hypoglycaemic effect, which is manifested by various mechanisms - inhibition of $\alpha$-glucosidase, stimulation of insulin secretion, increased glucose utilization; antioxidant effect due to its ability to prevent protein glycation and lipid peroxidation of the membrane, neutralizing the formed free radicals $[5,31]$.

The results of our research showed that the content of sinapic acid was $28.5 \mu \mathrm{g} / \mathrm{g}$ in sample $1,36.2 \mu \mathrm{g} / \mathrm{g}$ in sample $2,33.2 \mu \mathrm{g} / \mathrm{g}$ in sample $3,55.5 \mu \mathrm{g} / \mathrm{g}$ in sample 4 and $25.1 \mu \mathrm{g} / \mathrm{g}$ in sample 5 (Table II). Sinapic acid has numerous peripheral actions, such as antioxidant, anti-inflammatory, hypoglycaemic, cardioprotective, 
hepatoprotective and nephroprotective. Its hypoglycaemic effect is exerted by reducing insulin resistance and plasma glucose concentration, increasing the expression of the GLUT-4 gene in the skeletal muscle and cell sensitivity to insulin. In addition, it has the ability to regulate lipid metabolism by lowering triglycerides and cholesterol [6, 37].

It was established that the content of cinnamic acid in the second sample was $58.8 \mu \mathrm{g} / \mathrm{g}$, in sample $3-64.2$ $\mu \mathrm{g} / \mathrm{g}$, in sample $4-75.7 \mu \mathrm{g} / \mathrm{g}$, in sample $5-4.5 \mu \mathrm{g} / \mathrm{g}$ (Table II). Cinnamic acid exhibits antidiabetic properties by a variety of mechanisms of action, including stimulation of insulin secretion, improving the functioning of $\beta$-cells of the pancreas, inhibiting gluconeogenesis, increasing glucose uptake, improving glucose tolerance. In addition, it has antioxidant, hepatoprotective and anti-inflammatory effects $[1,16]$.

Caffeic acid was identified only in sample 1 and its content was $18.9 \mu \mathrm{g} / \mathrm{g}$ (Table II). It has high antioxidant, antidiabetic, anti-inflammatory effects and has the ability to protect the pancreas from destruction by free radicals and lipid peroxidation products [1, 29]. According to the literature, the vegetal products Helichrysum arenarium flowers, Urtica dioica leaf, Rosa majalis fruits, Zea mays columns with stigmas, Origanum vulgari herb, Vaccinium myrtillus leaf and Mentha piperita herb, contain cinnamic acid and its derivatives $[2,7,9,12,17,18]$. This aspect was also which was confirmed in our study by for the vegetal products from the herbal mixtures studied by our group. The relationship between the increase in the inhibitory activity of $\alpha$-amylase and $\alpha$-glucosidase and the concentration of aqueous extracts of herbal mixtures was evaluated. During the study of inhibition of $\alpha$ amylase enzyme it was established that the IC50 of the water extracts of the first sample was $699.49 \mu \mathrm{g} / \mathrm{mL}$, the second sample $2-758.15 \mu \mathrm{g} / \mathrm{mL}$, sample $3-$ $781.76 \mu \mathrm{g} / \mathrm{mL}$, sample $4-700.17 \mu \mathrm{g} / \mathrm{mL}$ and sample $5-646.52 \mu \mathrm{g} / \mathrm{mL}$ (Table III). Our results showed that the concentration required for $50 \%$ inhibition (IC50) of $\alpha$-glucosidase enzyme was 328.16 $\mu \mathrm{g} / \mathrm{mL}$ for sample $1,359.57 \mu \mathrm{g} / \mathrm{mL}$ for sample 2 , $342.73 \mu \mathrm{g} / \mathrm{mL}$ for sample $3,369.50 \mu \mathrm{g} / \mathrm{mL}$ for sample 4 and $292.55 \mu \mathrm{g} / \mathrm{mL}$ for sample 5 (Table IV). The IC50 value of standard drug acarbose against $\alpha$ amylase and $\alpha$-glucosidase was $246.22 \mu \mathrm{g} / \mathrm{mL}$ and $202.62 \mu \mathrm{g} / \mathrm{mL}$, respectively.

Thus, the establishment of the high content of cinnamic acid and its derivatives in the herbal mixtures studied and the assay of their in vitro antidiabetic activity by $\alpha$-amylase and $\alpha$-glucosidase inhibition may indicate these herbal mixtures as promising options for the management of diabetes and its complications.

\section{Conclusions}

The assay of cinnamic acid and its derivatives in the five different herbal mixtures with reliable antidiabetic activity was carried out. There were detected 4 derivatives of cinnamic acid, such as chlorogenic, caffeic, ferulic and sinapic acid in sample 1 of the herbal mixture (Urtica dioica leaf, Cichorium intybus roots, Rosa majalis fruits, Elymus repens rhizome, Taraxacum officinale roots); cinnamic acid and 4 its derivatives, such as chlorogenic, $p$-coumaric, ferulic and sinapic acid in the samples $2-5$. The high content of cinnamic acid and its derivatives contributed to the antidiabetic activity, which was confirmed trough in vitro of inhibition of $\alpha$-amylase and the $\alpha$-glucosidase.

\section{Acknowledgement}

This work was conducted within the scientific research work "Search the new species of medicinal plants, pharmacognostic and pharmacological justification of the effectiveness of their biologically active substances" No. of state registration 0118 U004982 approved by the Academic Council of I. Horbachevsky Ternopil National Medical University, Ternopil, Ukraine, protocol № 14 from 26.12.2018.

\section{Conflict of interest}

The authors declare no conflict of interest.

\section{References}

1. Adisakwattana $\mathrm{S}$, Cinnamic acid and its derivatives: mechanisms for prevention and management of diabetes and its complications. Nutrients, 2017; 9(2): 163: 1-27.

2. Alam MA, Subhan N, Hossain H, Hossain M, Reza HM, Rahman MM, Ullah MO, Hydroxycinnamic acid derivatives: a potential class of natural compounds for the management of lipid metabolism and obesity. Nutr Metab., 2016; 13: 27: 1-13.

3. American Diabetes Association, Improving Care and Promoting Health in Populations: Standards ofMedical Carein Diabetesd 2020. Diabetes Care, 2020; 43(Suppl. 1): S7-S13.

4. Budryn G, Zaczyńska D, Żyżelewicz D, Grzelczyk J, Zduńczyk Z, Juśkiewicz J, Influence of the form of administration of chlorogenic acids on oxidative stress induced by high fat diet in rats. Plant Foods Hum Nutr., 2017; 72(2): 184-191.

5. Bumrungpert A, Lilitchan S, Tuntipopipat S, Tirawanchai $\mathrm{N}$, Komindr S, Ferulic acid supplementation improves lipid profiles, oxidative stress, and inflammatory status in hyperlipidemic subjects: a randomized, doubleblind, placebo-controlled clinical trial. Nutrients., 2018; 10(6): 713: 1-8.

6. Chen C, Sinapic acid and its derivatives as medicine in oxidative stress-induced diseases and aging. Oxid Med Cell Longev., 2016; 2016: 3571614: 1-10.

7. Choudhury H, Pandey M, Hua CK, Mun CS, Jing JK, Kong L, Ern LY, Ashraf NA, Kit SW, Yee TS, Pichika MR, Gorain B, Kesharwani P, An update on natural compounds in the remedy of diabetes mellitus: A systematic review. J Tradit Complement Med., 2017; 8(3): 361-376.

8. Gothai S, Ganesan P, Park SY, Fakurazi S, Choi DK, Arulselvan P, Natural phyto-bioactive compounds 
for the treatment of type 2 diabetes: inflammation as a target. Nutrients, 2016; 8(8): 461: 1-28.

9. Guasch-Ferré M, Merino J, Sun Q, Fitó M, SalasSalvadó J, Dietary Polyphenols, Mediterranean Diet, Prediabetes, and Type 2 Diabetes: A Narrative Review of the Evidence. Oxid Med Cell Longev., 2017; 2017: 6723931: 1-16.

10. Ilavenil S, Kim da H, Srigopalram S, Arasu MV, Lee $\mathrm{KD}$, Lee JC, Lee JS, Renganathan S, Choi KC, Potential application of p-coumaric acid on differentiation of $\mathrm{C} 2 \mathrm{C} 12$ skeletal muscle and 3T3-L1 preadipocytesan in vitro and in silico approach. Molecules, 2016; 21(8): 997: 1-14.

11. International Diabetes Federation. IDF Diabetes Atlas, $9^{\text {th }}$ edition, Brussels, Belgium, 2019.

12. Kang GG, Francis N, Hill R, Waters D, Blanchard $\mathrm{C}$, Santhakumar AB, Dietary polyphenols and gene expression in molecular pathways associated with type 2 diabetes mellitus: A Review. Int J Mol Sci., 2019; 21(1): 140: 1-26.

13. Kooti W, Farokhipour M, Asadzadeh Z, AshtaryLarky D, Asadi-Samani M, The role of medicinal plants in the treatment of diabetes: a systematic review. Electron Physician, 2016; 8(1): 1832-1842.

14. Kumkrai P, Weeranantanapan O, Chudapongse N, Antioxidant, $\alpha$-glucosidase inhibitory activity and sub-chronic toxicity of Derris reticulata extract: its antidiabetic potential. BMC Complement Altern Med., 2015; 15: 35: 1-10.

15. Marchyshyn S, Polonets O, Savych A, Nakonechna $\mathrm{S}$, Determination of carbohydrates of Chrysanthemum morifolium L. leaves and flowers by GC-MS. Pharmakeftiki, 2020; 32(4): 202-212.

16. Mnafgui K, Derbali A, Sayadi S, Gharsallah N, Elfeki A, Allouche N, Anti-obesity and cardioprotective effects of cinnamic acid in high fat diet- induced obese rats. J Food Sci Technol., 2015; 52(7): 4369-4377.

17. Nasri H, Shirzad H, Baradaran A, Rafieian-Kopaei M, Antioxidant plants and diabetes mellitus. J Res Med Sci., 2015; 20(5): 491-502.

18. Oh YS, Jun HS, Role of bioactive food components in diabetes prevention: effects on Beta-cell function and preservation. Nutr Metab Insights., 2014; 7: 51-59.

19. Ong KW, Hsu A, Tan BK, Chlorogenic acid stimulates glucose transport in skeletal muscle via AMPK activation: a contributor to the beneficial effects of coffee on diabetes. PLoS One., 2012; 7(3): e32718: 1-11.

20. Orhan DD, Orhan N, Demir O, Konuklugil B, Phenolic content, antioxidant and in vitro antidiabetic effects of thirteen marine organisms from Mediterranean sea. Farmacia, 2021; 69(1): 68-74.

21. Pinto Mda S, Ghaedian R, Shinde R, Shetty K, Potential of cranberry powder for management of hyperglycemia using in vitro models. J Med Food., 2010; 13: 1036-1044.

22. Pyrzynska K, Sentkowska A, Chromatographic Analysis of Polyphenols. Polyphenols in Plants (Second Edition), Academic Press, 2019; 353-364.

23. Salazar-López NJ, Astiazarán-García H, GonzálezAguilar GA, Loarca-Piña G, Ezquerra-Brauer JM, Domínguez Avila JA, Robles-Sánchez M, Ferulic acid on glucose dysregulation, dyslipidemia, and inflammation in diet-induced obese rats: An integrated study. Nutrients, 2017; 9(7): 675: 1-13.

24. Santana-Gálvez J, Cisneros-Zevallos L, JacoboVelázquez DA, Chlorogenic acid: Recent advances on its dual role as a food additive and a nutraceutical against metabolic syndrome. Molecules., 2017; 22(3): 358: 1-21.

25. Savych A, Marchyshyn M, Basaraba R, Screening study of hypoglycemic activity of the herbal mixtures (Message 1). ScienceRise: Pharmaceutical Science, 2020; 4(26): 40-46.

26. Savych A, Marchyshyn S, Harnyk M, Kudria V, Ocheretniuk A, Determination of amino acids content in two samples of the plant mixtures by GC-MS. Pharmacia, 2021; 68(1): 283-289.

27. SavychA, Marchyshyn S, Kozyr H, Yarema N, Determination of inulin in the herbal mixtures by GC-MS method. Pharmacia, 2021; 68(1): 181-187.

28. Skyler JS, Bakris GL, Bonifacio E, Darsow T, Eckel RH, Groop L, Groop PH, Handelsman Y, Insel RA, Mathieu C, McElvaine AT, Palmer JP, Pugliese A, Schatz DA, Sosenko JM, Wilding JP, Ratner RE, Differentiation of diabetes by pathophysiology, natural history, and prognosis. Diabetes, 2017; 66(2): 241-255.

29. Stähli A, Maheen CU, Strauss FJ, Eick S, Sculean A, Gruber R, Caffeic acid phenethyl ester protects against oxidative stress and dampens inflammation via heme oxygenase 1. Int J Oral Sci., 2019; 11(1): 6: $1-8$.

30. Sumere BR, de Souza MC, Dos Santos MP, Bezerra RN, da Cunha DT, Martinez J, Rostagno MA, Combining pressurized liquids with ultrasound to improve the extraction of phenolic compounds from pomegranate peel (Punica granatum L.). Ultrason Sonochem., 2018; 48: 151-162.

31. Tao ZH, Li C, Xu XF, Pan YJ, Scavenging activity and mechanism study of ferulic acid against reactive carbonyl species acrolein. J Zhejiang Univ Sci B., 2019; 20(11): 868-876.

32. Teixeira J, Gaspar A, Garrido EM, Garrido J, Borges F, Hydroxycinnamic acid antioxidants: an electrochemical overview. Biomed Res Int., 2013; 2013: 251754: 1-11.

33. Tohge $T$, Watanabe M, Hoefgen R, Fernie AR, Shikimate and phenylalanine biosynthesis in the green lineage. Front Plant Sci., 2013; 4: 62: 1-13.

34. Tsang MS, Jiao D, Chan BC, Hon KL, Leung PC, Lau CB, Wong EC, Cheng L, Chan CK, Lam CW, Wong CK, Anti-inflammatory activities of pentaherbs formula, berberine, gallic acid and chlorogenic acid in atopic dermatitis-like skin inflammation. Molecules., 2016; 21(4): 519: 1-21.

35. Watanabe T, Kobayashi S, Yamaguchi T, Hibi M, Fukuhara I, Osaki N, Coffee abundant in chlorogenic acids reduces abdominal fat in overweight adults: A randomized, double-blind, controlled trial. Nutrients, 2019; 11(7): 1617: 1-13.

36. WHO Guidelines on Good Agricultural and Mixture Practices (GACP) for Medicinal Plants. World Health Organization, Geneva, 2003; 72 (https://apps.who.int).

37. Zych M, Kaczmarczyk-Sedlak I, Wojnar W, Folwarczna $\mathrm{J}$, The effects of sinapic acid on the development of metabolic disorders induced by estrogen deficiency in rats. Oxid Med Cell Long., 2018; 2018: 9274246: 1-11. 